\title{
Device Damaged Prior to Use
}

National Cancer Institute

\section{Source}

National Cancer Institute. Device Damaged Prior to Use. NCI Thesaurus. Code C63015.

Problem associated with packaging or shipping damage prior to the use of a device. 